\title{
ČITATELJSKI KLUBOVI U NARODNIM KNJIŽNICAMA VELIKIH HRVATSKIH GRADOVA
}

\author{
BOOK CLUBS IN THE PUBLIC LIBRARIES \\ OF LARGE CROATIAN CITIES
}

\author{
Mirko Duić \\ Odjel za informacijske znanosti, \\ Sveučilište u Zadru \\ mduic@unizd.hr \\ Mihaela Anđić \\ Arheološki muzej u Zadru \\ mihaela.andic@gmail.com
}

UDK / UDC [028:061.2]: 027.022

Izvorni znanstveni rad / Original scientific paper

Primljeno / Received: 27. 8. 2019.

Prihvaćeno / Accepted: 16. 10. 2019.

\section{Sažetak ${ }^{1}$}

Cilj. Istražiti prisutnost, obilježja i prakse čitateljskih klubova u narodnim knjižnicama velikih hrvatskih gradova. Također, cilj rada bio je istražiti iskustva i preporuke njihovih voditelja vezano uz uspješan rad čitateljskih klubova.

Metodologija. U radu je korištena metoda ankete. Anketirano je jedanaest voditelja čitateljskih klubova u narodnim knjižnicama u Splitu, Rijeci, Osijeku, Zadru i Puli.

Rezultati. Neki od uvida stečenih istraživanjem jesu: sastanci u čitateljskim klubovima uglavnom se održavaju jednom mjesečno, traju od jednog do dva sata, a mjesto sastanka najčešće je knjižnica; članovi klubova većinom su žene; u određenim knjižnicama ne postoje čitateljski klubovi za ljude određenih životnih dobi; najčešća aktivnost koja se odvija na sastancima jest rasprava o knjigama, ali su prisutne i razne druge

\footnotetext{
1 Rad je nastao na temelju diplomskog rada studentice Mihaele Anđić pod nazivom Raširenost $i$ praksa čitateljskih klubova u hrvatskim narodnim knjižnicama i pod mentorskim vodstvom Mirka Duića. Rad je obranjen na Sveučilištu u Zadru 2018. godine.
} 
aktivnosti, od susreta s piscima do društvenih igara i crtanja; glavni kriteriji za odabir knjiga za čitanje jesu želje korisnika i dostupnost knjiga; u većini klubova članovi čitaju pretežno stranu literaturu.

Praktična primjena. Rad pruža različite uvide koji mogu biti korisni voditeljima čitateljskih klubova, kao i drugim zainteresiranima, da unaprijede ili pokrenu djelatnost čitateljskih klubova.

Originalnost/vrijednost. Prikazani su bitni aspekti djelovanja čitateljskih klubova u narodnim knjižnicama velikih hrvatskih gradova. Istražena je tema koja nije često zastupljena u domaćoj literaturi.

Ključne riječi: čitanje, čitateljski klubovi, knjiški klubovi, narodne knjižnice, promicanje čitanja

\section{Abstract}

Objective. The first objective of this paper was to explore the presence, characteristics and practices of book clubs in the public libraries of large Croatian cities. The second objective was to explore the experiences of book club leaders and their recommendations related to successful activities of book clubs.

Methodology. The survey method was used to accomplish the research objectives. Eleven book club leaders in the public libraries of the cities Split, Rijeka, Osijek, Zadar and Pula, were surveyed.

Findings. These are some of the research findings: meetings in book clubs are held once a month, they last from one to two hours and the meeting place is usually in the library; the book club members are mostly women; there are certain libraries which do not have a book club for persons of certain ages; the most common activity that takes place in the meetings is book discussion, but other activities are also present from meetings with writers to board games and drawing; the main criteria for selecting books to read are user preferences and availability of books; in majority of reading clubs the members read mostly foreign literature.

Practical implications. The paper provides various insights that may be useful to book club leaders, as well as for other interested parties, to improve or initiate book club activities.

Originality/value. Essential aspects of the activities of book clubs in the public libraries of the major Croatian cities are presented. A topic that is seldom represented in domestic scientific or professional literature is explored.

Keywords: book clubs, public libraries, reading, reading clubs, reading promotion 


\section{Uvod}

Narodne knjižnice imaju važnu ulogu u razvoju i izgradnji demokratskog društva, osiguravajući svakom pojedincu pristup širokom i raznolikom spektru znanja, ideja i mišljenja. ${ }^{2}$ Neki od glavnih ciljeva narodnih knjižnica jesu i zadovoljavanje obrazovnih, informacijskih i kulturnih potreba stanovništva. ${ }^{3}$ Otvorene su za sve zainteresirane i omogućuju ljudima da u njima slobodno borave pružajući im razne usluge. Narodne su knjižnice mjesta gdje se čuvaju, čitaju i posuđuju knjige, ali i mjesta susreta, mjesta kvalitetnog provođenja slobodnog vremena uz razne aktivnosti. One su mjesta razvoja pojedinca i zajednice u kreativnom, kulturnom i obrazovnom smislu. Jedna je od bitnih zadaća narodnih knjižnica promicanje čitanja. Mnogo je načina za ostvarenje te zadaće, naprimjer knjižnični čitateljski klub promiče čitanje okupljajući i gradeći zajednicu čitatelja, ljudi s interesom prema čitanju, koji o pročitanome žele razmijeniti mišljenja i razgovarati. Članovi knjižničnog čitateljskog kluba razvijaju interes za čitanje kvalitetne literature, potiče ih se da čitaju redovito i dobivaju ugodan prostor u kojemu s drugim strastvenim čitateljima mogu dijeliti svoja čitateljska i životna iskustva, mišljenja i dojmove. U ovome radu istražit ćemo djelovanje čitateljskih klubova u hrvatskim narodnim knjižnicama.

\section{2. Čitateljski klubovi}

\subsection{Osnovne značajke čitateljskih klubova}

Plevnik u knjizi Tolle lege piše o nastanku čitateljskih klubova. Navodi kako je prvi sličan klub bila Platonova Akademija još 357. g. pr. n. e. u kojoj su filozofi i njihovi učenici raspravljali o pročitanome. U srednjem vijeku čitateljske su se grupe sastajale u samostanima gdje su se knjige čitale, prevodile i prepisivale. U 17. st. u Francuskoj počinju okupljanja u takozvanim damskim salonima kako bi čitatelji raspravljali i razmjenjivali mišljenja o pročitanome, a glavnu riječ vodile su ugledne plemkinje. ${ }^{4}$ Jürgen Habermas tvrdi kako su se zajedno s razvojem romana kao književnog žanra u 18. stoljeću razvila i književna društva. Njihov je razvoj pomogao razvoju moderne srednje klase, širenju čitateljske publike i razvoju književne i političke javne sfere. ${ }^{5}$ Početkom 19. st. počela su se razvijati

\footnotetext{
2 Usp. IFLA-ine smjernice za narodne knjižnice / uredile Christie Koontz i Barbara Gubbin. 2. hrvatsko izd. Zagreb: Hrvatsko knjižničarsko društvo, 2011. Str. 15.

3 Usp. Pejić, I. Narodne knjižnice: potpora formalnom i neformalnom obrazovanju - visoko obrazovanje. // Radovi Zavoda za znanstvenoistraživački i umjetnički rad u Bjelovaru, 3(2009), str. 98.

4 Usp. Plevnik, D. Tolle lege: za slobodu čitanja. Zagreb: Nacionalna i sveučilišna knjižnica, 2012. Str. 108.

5 Usp. Habermas, J. The structural transformation of the public sphere: an inquiry into a category of bourgeois society. MIT Press, 1991. Citirano prema: Tyler, J. E. The people who do
} 
čitateljska društva u SAD-u na čijim počecima žene raspravljaju o poeziji. Druga polovina 20. st. razdoblje je kada se u svijetu osniva najviše čitateljskih klubova. ${ }^{6}$ Današnji čitateljski klubovi imaju različite prakse. Bilo da nalikuju nekadašnjim književnim ili damskim salonima, bilo da se zovu čitateljske grupe ili klubovi knjiga, sve su to najčešće male zajednice individualnih čitatelja koje povezuju interesi za književnost, društvenu interakciju i učenje. ${ }^{7} \mathrm{U}$ prethodnim su se stoljećima u čitateljskim klubovima uglavnom okupljali ljudi viših staleža, plemići ili redovnici u samostanima. Danas član kluba može biti bilo tko, važno je da ima interes za knjigu, čitanje te razgovor i druge aktivnosti vezane uz čitanje.

Čitateljski je klub grupa ljudi koji se sastaju i razgovaraju o pročitanim knjigama. Ljudi se okupljaju u klubu radi zajedničke strasti prema čitanju, zabave, veselja i smijeha, stvaranja prijateljstava, stalnosti i sigurnosti, stvaranja dobrih navika, ali i zbog toga što osjećaju ponos i čast pripadanja grupi. ${ }^{8}$ Oni vole dolaziti na sastanke čitateljske grupe zbog posebne atmosfere koju karakteriziraju iskrenost, opuštenost te uvažavanje različitih mišljenja. Način razgovora u grupi razlikuje se od svakodnevne komunikacije. Često se razgovara o kompleksnim temama, npr. o moralnim i estetskim pitanjima. Postoje specijalizirani čitateljski klubovi. U nekim klubovima čita se samo određeni tip literature, npr. poezija, znanstvenofantastična i komična djela, a u nekima se proučavaju samo određene teme, npr. povijest, pa se uglavnom čitaju povijesni romani i djela povijesne znanosti. Postoje i klubovi u kojima se čitaju samo djela određenih autora, npr. djela Williama Shakespearea. ${ }^{9}$ Moguća je podjela čitateljskih klubova s obzirom na broj istodobno čitanih tekstova. U jednonaslovnim klubovima (engl. single title) svi članovi istodobno čitaju isti naslov, najčešće djelo fikcije. U višenaslovnim klubovima (engl. multi-title) članovi istodobno čitaju različite naslove na zadanu temu te potom razmjenjuju saznanja. ${ }^{10}$ Čitateljski klubovi sastanke mogu održavati u učionici, restoranu, knjižnici, kući člana, čak i na otvorenom. Članovi se najčešće sastaju jednom mjesečno. Mogu biti raznih uzrasta, od predškolske djece do umirovljenika. ${ }^{11}$ Postoje naprimjer čitateljski klubovi za odrasle, studente, roditelje,

\footnotetext{
'this' in common: book clubs as 'everyday activists': doktorska disertacija. Knoxville: University of Tennessee, 2014. Str. 43. [citirano: 2019-10-14]. Dostupno na: https://trace.tennessee.edu/ utk_graddiss/2778/.

6 Usp. Plevnik, D. Nav. dj., str. 119-121.

7 Usp. Habermas, J. Nav. dj., str. 27.

8 Usp. Bašić, I. O čitateljskim grupama: metodički priručnik s primjerima dobre prakse. Zagreb: Balans centar za logopedagogiju i biblioterapiju, 2014. Str. 27.

9 Usp. Alvarez-Alvarez, C. Book clubs: an etnographic study of an innovative reading practice in Spain. // Studies in Continuing Education 38, 2(2016), str. 2.

10 Usp. Bašić, I. Nav. dj., str. 53.

11 Usp. Kosmicki, E. A. A book club for children with autism spectrum disorder: a thesis submitted in partial fulfillment of the requirements for the designation University Honors with Dis-
} 
djecu i mlade. ${ }^{12}$ Osim čitanja, sastanak kluba može uključivati razne sadržaje poput izleta i posjeta književnika. Ono što povezuje sve klubove jest čitanje određenih tekstova i razgovor o njima. ${ }^{13}$

\section{2. Čitateljski klubovi u hrvatskim narodnim knjižnicama}

Čitateljski klubovi koji djeluju u narodnim knjižnicama sve su rašireniji. Budući da je narodna knjižnica mjesto okupljanja i druženja kojoj svaki član zajednice ima pristup, a ujedno je i mjesto gdje su pohranjeni brojni izvori pisane riječi, idealno je mjesto za okupljanje ljudi koji vole čitati i razgovarati o pročitanome. Osim što je koristan zainteresiranim članovima knjižnice koji u njemu dobivaju mjesto za druženje i razgovor o pročitanome, čitateljski klub obogaćuje sadržaje koje pruža knjižnica. U hrvatskim narodnim knjižnicama čitateljski klubovi nisu rijetkost. Iznenađujuće je stoga što o toj temi ne postoji veći broj domaćih znanstvenih i stručnih radova. Tako naprimjer ne nalazimo radove na tu temu ni u bibliografiji hrvatskih znanstvenih i stručnih radova s temom knjižničnih usluga i službi iz perspektive korisnika. Autorice su pronašle 147 radova objavljenih od 1991. do kraja 2016. koje su podijelile u deset tematskih cjelina. ${ }^{14}$ Jedna od cjelina jest 'Razne druge aktivnosti informativne službe'. U njoj bi trebali biti radovi koji se odnose na knjižnične čitateljske klubove, izložbe, tribine, promotivne aktivnosti, suradnju s drugim institucijama. ${ }^{15}$ Međutim od 147 radova u bibliografiji tek četiri rada pripadaju u ovu cjelinu. Nijedan od njih kao glavnu temu nema čitateljske klubove. ${ }^{16}$

Pregledom literature pronašli smo ipak nekoliko relevantnih radova vezanih uz čitateljske klubove u hrvatskim knjižnicama. Iako glavna tema tih radova pretežno nije izravno vezana uz čitateljske klubove, oni se u njima tematiziraju putem povezanosti s glavnom temom.

Bokan i Cupar istražile su na koje se sve načine u 35 hrvatskih narodnih knjižnica promovira i promiče čitanje. Rezultati istraživanja dobiveni intervjuima s knjižničarima ukazuju na to da se u deset knjižnica provode aktivnosti promicanja čitanja putem čitateljskog kluba za mlade, a u devet knjižnica provode se aktivnosti promicanja čitanja putem čitateljskog kluba za odrasle. Ovaj nam istraživački

\footnotetext{
tinction. University of Northern Iowa, 2016. Str. 5. [citirano: 2019-10-14]. Dostupno na: https:// scholarworks.uni.edu/cgi/viewcontent.cgi? article $=1228 \&$ context $=$ hpt.

12 Usp. Healy, A. Giving readers a voice: book discussion groups. [citirano: 2019-08-24]. Dostupno na: http://www.ala.org/aboutala/offices/publishing/booklist/booklinks/resources/bookdiscussion.

13 Usp. Kosmicki, E. A. Nav. dj., str. 5.

14 Usp. Aleksić, Lj.; S. Zec. Knjižnične usluge i službe s gledišta korisnika: prilozi za bibliografiju. // Vjesnik bibliotekara Hrvatske 60, 2-3(2017), str. 318-319.

15 Usp. Isto, str. 335-336.

16 Usp. Isto, str. 333-334.
} 
uvid potvrđuje da značajan broj hrvatskih knjižnica ima čitateljske klubove. ${ }^{17}$ Vrana i Kovačević istražili su jake i slabe točke u radu Knjižnice i čitaonice Bogdana Ogrizovića, jedne od knjižnica u mreži Knjižnica grada Zagreba. Istraživanje je provedeno metodom ankete, a ispitanici su odgovarali i na pitanje o tome koje bi aktivnosti željeli u knjižnici. ${ }^{18}$ Pojedini ispitanici izrazili su želju da knjižnica pokrene književne klubove za odrasle i srednjoškolce. ${ }^{19}$ Bokan i Poljak usporedile su poslovanje Gradske knjižnice i čitaonice Pula s Gradskom knjižnicom Rovaniemi u Finskoj, kako bi pronašle čimbenike koji imaju utjecaj na to da korisnici provode slobodno vrijeme čitajući u knjižnici. Utvrđeno je da se pulska knjižnica fokusirala na promicanje čitanja najmlađih korisnika. Knjižnica stoga ima različite aktivnosti, među kojima su dječji čitateljski klub te klub čitatelja za mlade.$^{20}$ Krpan, Mršić i Cej pišu o primjeni razvojne biblioterapije na odjelima za djecu i mlade u narodnim knjižnicama. Autorice ukazuju na to da biblioterapijske radionice $u$ knjižnicama doprinose razvoju socijalnih i emocionalnih kompetencija djece, potiču ih na čitanje, razvijaju naviku čitanja i jačaju komunikacijske vještine. Preporučuju da se ove radionice provode u sklopu čitateljskih klubova i grupa. Također ukazuju na to da Knjižnice grada Zagreba provode brojne programe razvojne biblioterapije među kojima značajno mjesto zauzimaju upravo aktivnosti u sklopu čitateljskih klubova za djecu i mlade. ${ }^{21}$ Kolarić i suradnici opisuju nesvakidašnje čitateljske klubove smještene u virtualnom prostoru. Radi se o blogovima narodnih knjižnica u Bjelovaru, Rijeci, Vinkovcima i Zadru, blogovima koji postaju mrežni čitateljski klubovi za djecu i mlade. Dječji odjel narodne knjižnice Zadar 2011. je godine svoj tradicionalni izbor knjige ljeta prebacio s oglasne ploče na blog. Osobito ga prihvaćaju djeca u dobi od 10 do 13 godina. O knjigama predstavljenim na blogu uskoro se razvijaju brojne rasprave pa izbor najbolje knjige prerasta u mrežni čitateljski klub. Zadarska knjižnica potom nudi podršku za osnivanje sličnih mrežnih čitateljskih klubova narodnim knjižnicama u Bjelovaru, Rijeci i Vinkovcima, koje prijedlog prihvaćaju. Stvara se čitateljski blog za djecu 'Tragači' te blog za mlade 'Knjiški frikovi'. Cilj je obaju blogova poticati ljubav prema knjigama i čitanju. ${ }^{22}$ 'Tragači' su namijenjeni ljubiteljima čitanja u dobi od

17 Usp. Bokan, A.; D. Cupar. Promocija i promicanje čitanja u narodnim knjižnicama Republike Hrvatske. // Libellarium 10, 1(2017), str. 66. [citirano: 2019-10-14]. Dostupno na: http://www. libellarium.org/index.php/libellarium/article/view/290.

18 Usp. Vrana, R.; J. Kovačević. Kakvu narodnu knjižnicu želimo? Istraživanje korisnika Knjižnice i čitaonice Bogdana Ogrizovića. // Vjesnik bibliotekara Hrvatske 61, 2(2018), str. 54-55.

19 Usp. Isto, str. 67.

20 Usp. Bokan, A.; Lj. Poljak. Provođenje slobodnog vremena čitajući u knjižnici. // Vjesnik bibliotekara Hrvatske 61, 1(2018), str. 187.

${ }^{21}$ Usp. Krpan, K.; I. Klak Mršić; V. Cej. Primjena razvojne biblioterapije u radu s djecom i mladima u narodnoj knjižnici. // Vjesnik bibliotekara Hrvatske 61, 1(2018), str. 356-358.

22 Usp. Kolarić, A.; S. Šimić; V. Štivić; Ž. Žentil Barić. Čitateljski blogovi Tragači i Knjiški frikovi: usluge za djecu i mlade na Web-u 2.0. // Vjesnik bibliotekara Hrvatske 56, 3(2013), str. 91-93. 
8 do 13 godina. Način rada s djecom na čitateljskom blogu bitno se ne razlikuje od vođenja čitateljskog kluba u prostorima knjižnice. Knjižničarke redovno postavljaju teme i pitanja za raspravu o knjizi koja se čita određeni mjesec, a djeca rješavaju zadatke i pišu o pročitanom. Organiziraju se i povremena mrežna druženja s piscima, a djeca si međusobno preporučuju knjige. 'Knjiški frikovi' su blog za mlade od 13 do 18 godina. Sadržajima ga pune prvenstveno mladi koji pišu razne priloge, preporuke knjiga, autorske tekstove. ${ }^{23}$

Uvidi o radu čitateljskih klubova u zagrebačkim narodnim knjižnicama nalaze se u diplomskom radu Anamarije Stepanić. Istraživanje je provedeno 2014. godine tako što su na odabranim susretima čitateljskih klubova anketni upitnik ispunile sve prisutne osobe. Ukupno su anketirana 54 člana pet čitateljskih klubova u tri različite knjižnice. Istraživanjem se nastojalo utvrditi prakse čitateljskih klubova u narodnim knjižnicama te preduvjete potrebne da čitateljski klub zaživi i opstane u narodnoj knjižnici. Utvrđeno je da na sastanke čitateljskih klubova dolaze većinom žene - čak $91 \%$. Među ispitanicima podjednako su bile zastupljene sve dobne skupine, osim skupine osoba starijih od 60 godina koja je gotovo dvostruko brojnija od ostalih. Što se tiče obrazovanja, najviše je članova visoke ili više stručne spreme ( $74 \%$ ). $43 \%$ ispitanika za je sebe reklo da čita puno, i to raznoliku literaturu. Gotovo polovica ispitanika navela je da mjesečno pročita 2 ili 3 knjige, a čak $13 \%$ ispitanika pročita i 5 do 8 knjiga mjesečno. Što se tiče pitanja vezanih uz čitateljski klub, situacija je sljedeća. Najviše je ispitanika (74 \%) odgovorilo da je za čitateljski klub saznalo u knjižnici, a isto toliko njih je odgovorilo da su zadovoljni odabirom knjiga u klubu. Većina ispitanika odgovorila je da je najveća motivacija za sudjelovanje u klubu razgovor o pročitanome. Gotovo svim ispitanicima ispunjena su očekivanja koja su imali od kluba te rijetko izostaju sa sastanaka. Kada je riječ o odabiru knjiga, 70 \% njih misli da bi knjige trebao birati voditelj, a tri kriterija koje navode kao najvažnije pri odabiru knjiga jesu da je netko već pročitao knjigu i ima pozitivno mišljenje o njoj, da knjiga ima literarnu vrijednost i da govori o važnim društvenim temama. ${ }^{24}$

Bašić je napisala metodički priručnik o čitateljskim grupama s primjerima dobre prakse. Pružen je pregled različitih čitateljskih grupa u Hrvatskoj, a kao primjer predstavit ćemo čitateljske grupe u Zadru. ${ }^{25}$ U Gradskoj knjižnici Zadar, za vrijeme pisanja priručnika, djeluje osam čitateljskih klubova namijenjenih različitim uzrastima. Prvi čitateljski klubovi osnivaju se 2009. kada ih je nastalo čak četiri. Dioptrija je klub čitatelja za tinejdžere u dobi od 13 do 16 godina. Iste godine osnovani su i Klub čitatelja za mlade Bili Brig te Klub čitatelja Boris Maruna. Prvi klub vodila je profesorica hrvatskog jezika, a okupljao je većinom ženske članice u dobi od 15 go-

23 Usp. Isto, str. 95-96.

24 Usp. Stepanić, A. Čitateljski klubovi u zagrebačkim narodnim knjižnicama: diplomski rad.. Zagreb: Filozofski fakultet Sveučilišta, 2014. Str. 15-33.

25 Bašić, I. Nav. dj. 
dina naviše. Drugi klub vodio profesor književnosti i u njemu se okupljalo desetak članova različitog spola i godišta. Posljednji klub osnovan 2009. godine bio je Klub čitatelja ogranka Arbanasi. Vodila ga je knjižničarka i u njemu se sastajalo desetak žena različitih dobi. Sljedeće godine osnovana su dva čitateljska kluba namijenjena djeci u dobi od 8 do 12 godina. Knjigolovci su čitateljski klub za djecu u dobi od 8 do 12 godina, čiji su članovi većinom bile djevojčice. Tu su još i Klub čitatelja za djecu Bili Brig te Klub čitatelja za tinejdžere u kojemu su sastanci često bili dvaput mjesečno. U Ogranku Arbanasi 2011. godine osnovan je Klub čitatelja za djecu Arbanasi. Članovi kluba bila su djeca u dobi od 10 do 14 godina. ${ }^{26}$

Zbog originalnog načina rada $\mathrm{s}$ mladima vrijedi predstaviti čitateljski klub Flâneuri iz susjedne države. Ivanković i Mlinko pisale su o radu ovog kluba za tinejdžere, koji od 2015. djeluje u Gradskoj knjižnici Subotica u Srbiji. Cilj je kluba:

,interdisciplinarnim pristupom brisati granice među umjetnostima te klasičnom i virtualnom šetnjom potaknuti kod mladih čitatelja gastronomiju oka i duha. ${ }^{\text {"27 }}$

U klubu se koriste nekonvencionalne metode rada. Svaki susret zasnovan je na šetnji članova kluba kroz knjižnicu, literaturu, grad i njegovu povijest, na virtualnoj šetnji i drugim vrstama šetnje. Također, svaki susret članova je stvaralački. Cilj je da mladi stvaraju vlastite duhovne proizvode, npr. crtež, fotografiju, plakat, pisanu ili izgovorenu riječ, kako bi oplemenili življenje. ${ }^{28}$ Naprimjer tema jednog susreta bila je recikliranje riječi. Mladi su na papir ispisali uvredljive riječi, potom su ih izrezali na pojedina slova te ova slova presložili u pozitivne riječi koje svatko voli čuti. Novodobivene riječi zalijepili su na stepenicama knjižnice. Također, jedni drugima čitali su prigodne ulomke iz književnih djela. Dvadesetak članova čitateljskog kluba Flâneuri susreće se jednom mjesečno na različitim lokacijama, ovisno o planiranoj temi i šetnji. ${ }^{29}$

\section{Istraživanje}

\subsection{Cilj istraživanja}

Cilj ovog rada bio je istražiti prisutnost, obilježja i prakse čitateljskih klubova u narodnim knjižnicama velikih hrvatskih gradova. Također, cilj rada bio je istražiti iskustva i preporuke njihovih voditelja vezano uz uspješan rad čitateljskih klubova. Svrha je rada pružiti uvide koji mogu biti temelj za unapređenje djelatnosti čitateljskih klubova te ukazati na njihovu važnost kao pogodnih mjesta za razvoj čitateljske kulture.

\footnotetext{
26 Isto, str. 13-21.

27 Ivanković, B.; N. Mlinko. Knjižnica kao prostor flanerije. // Vjesnik bibliotekara Hrvatske 60, 1(2017), str. 183.

28 Usp. Isto, str. 186.

29 Usp. Isto, str. 188-189.
} 


\subsection{Metodologija, instrument i uzorak}

Istraživanje je provedeno $u$ šest narodnih knjižnica u najvećim hrvatskim gradovima: Gradska knjižnica Marka Marulića u Splitu ${ }^{30}$, Gradska knjižnica Rijeka ${ }^{31}$, Gradska i sveučilišna knjižnica Osijek ${ }^{32}$, Gradska knjižnica Zadar ${ }^{33}$, Gradska knjižnica Slavonski Brod ${ }^{34}$ te Gradska knjižnica i čitaonica Pula. ${ }^{35}$ Odabrane su knjižnice u hrvatskim gradovima većim od 50000 stanovnika. U istraživanje nisu uključene Knjižnice grada Zagreba jer su aspekti djelovanja čitateljskih klubova u toj mreži knjižnica već istraženi u radu Anamarije Stepanić, dok za čitateljske klubove u knjižnicama koje smo uključili u istraživanje nisu pronađena slična istraživanja. ${ }^{36}$

U istraživanju je korištena metoda ankete. Ankete su u lipnju 2018. godine elektroničkom poštom poslane na adrese voditelja čitateljskih klubova: za četiri voditelja u Gradskoj knjižnici Marka Marulića u Splitu, za osam voditelja u Gradskoj knjižnici Rijeka, za jednog voditelja u Gradskoj i sveučilišnoj knjižnici Osijek, za tri voditelja u Gradskoj knjižnici Zadar te za dva voditelja u Gradskoj knjižnici i čitaonici Pula. Pristiglo je 11 odgovorenih i popunjenih anketa, a iz svake je knjižnice odgovorio bar jedan voditelj čitateljskog kluba. Preciznije, odgovore su poslali dva voditelja iz Splita, četiri voditelja iz Rijeke, jedan voditelj iz Osijeka, dva voditelja iz Zadra te dva voditelja iz Pule. Jedna voditeljica iz Rijeke i jedna voditeljica iz Zadra voditeljice su dvaju, odnosno triju klubova pa su na neka pitanja odgovarale posebno za svaki klub. Pojedine čitateljske klubove u predstavljanju rezultata označili smo na sljedeći način: Gradska knjižnica Marka Marulića Split: ČKS1, ČKS2; Gradska knjižnica Rijeka: ČKR1, ČKR2, ČKR3, ČKR4; Gradska i sveučilišna knjižnica Osijek: ČKO1; Gradska knjižnica Zadar: ČKZ1, ČKZ2; Gradska knjižnica i čitaonica Pula: ČKP1, ČKP2.

Anketa se sastojala od 25 pitanja otvorenog tipa, a pet pitanja među njima imalo je dopunska pitanja kako bi se tema potpunije istražila. Postavljena su pitanja o članovima klubova (broj, dob i spol članova) i sastancima klubova (mjesto, duljina i učestalost održavanja sastanaka), o promoviranju klubova i aktivnostima pridobivanja novih članova, o odabiru knjiga za sastanke (tko bira knjige, kriteriji odabira, tipovi odabranih knjiga, omjer domaćih $i$ stranih autora), o tome na koji se način na sastancima klubova vodi rasprava (načini poticanja rasprave, učestalost uključivanja u rasprave, opis primjera rasprave, primjeri pitanja za raspravu), o prednostima i nedostacima čitateljskih klubova, o poteškoćama u radu kluba, ciljevima i aktivnostima klubova te o iskustvima njihovih voditelja i njihovim preporukama za one koji žele osnovati čitateljski klub (prilog 1).

30 Gradska knjižnica Marka Marulića u Splitu. [2019-08-24]. Dostupno na: https://www.gkmm.hr.

31 Gradska knjižnica Rijeka. [2019-08-24]. Dostupno na: https://gkr.hr.

32 Gradska i sveučilišna knjižnica Osijek. [2019-08-24]. Dostupno na: https://www.gskos.unios.hr.

33 Gradska knjižnica Zadar. [2019-08-24]. Dostupno na: www.gkzd.hr.

34 Gradska knjižnica Slavonski Brod. [2019-08-24]. Dostupno na: https://www.gksb.hr.

35 Gradska knjižnica i čitaonica Pula. [2019-08-24]. Dostupno na: www.gkc-pula.hr.

36 Stepanić, A. Nav. dj. 


\subsection{Rezultati}

U ovom dijelu rada predstavljamo rezultate ankete provedene među voditeljima čitateljskih klubova u odabranim knjižnicama.

Koliko članova ima čitateljski klub u vašoj knjižnici? Ispitani čitateljski klubovi broje između 7 i 20 članova. Dakle u prosjeku se čitateljski klub sastoji od oko 14 članova. Najmanje članova, njih sedam, imaju jedan čitateljski klub iz Pule i jedan iz Splita, dok najveći broj od 20 članova ima čitateljski klub iz Osijeka. Voditeljica jednog čitateljskog kluba nije odgovorila na pitanje.

Imate li članove svih uzrasta? U kojoj je otprilike dobi najviše članova kluba? Kao što se vidi u tablici 1, svi uzrasti podjednako su zastupljeni. U skupinu djece ubrojali smo svu predškolsku i osnovnoškolsku djecu do 14 godina, u skupinu mladih one od 15 do 32 godine, a u posljednju skupinu sve ostale. Dobne skupine odredili smo prema odgovorima voditelja. Voditelji su većinom odgovarali komu je klub namijenjen (djeci, mladima, studentima ili odraslima) te su uz to navodili koje su dobi članovi. Stoga su prema njihovim odgovorima formirane dobne skupine.

Tablica 1. Dob članova

\begin{tabular}{|c|c|}
\hline Dob članova & Broj knjižnica \\
\hline djeca & 4 \\
\hline mladi & 5 \\
\hline odrasli & 5 \\
\hline
\end{tabular}

Koliko je otprilike muških, a koliko ženskih članova? Kada je u pitanju spol članova klubova, uvjerljivo prevladavaju žene. U tablici 2 može se vidjeti da je od svih istraženih čitateljskih klubova gotovo polovina isključivo ženskih, a nijedan nije isključivo muški. Među klubovima u kojima imamo i muške i ženske članove, šest čitateljskih klubova ima više ženskih članova, i to uglavnom znatno više ženskih članova, jedan klub ima podjednako muških i ženskih članova, a samo jedan klub ima više muških nego ženskih članova.

Tablica 2. Spol članova čitateljskih klubova

\begin{tabular}{|c|c|}
\hline Spol članova & Broj klubova \\
\hline ženski & 6 \\
\hline muški & 0 \\
\hline oboje & 8 \\
\hline
\end{tabular}


Kako sve potencijalni članovi kluba mogu saznati da klub postoji i koje su mu aktivnosti? Kako pridobivate nove članove? Najučestaliji način obavještavanja potencijalnih članova o postojanju kluba je usmena predaja - devet ispitanika koristi tu metodu. Ona podrazumijeva preporuku od strane aktivnih članova klubova, njihovih roditelja, prijatelja, odnosno bilo koga tko je upoznat s postojanjem i radom kluba. Gotovo svi ispitanici naglasili su da je to najučinkovitiji način promocije te da ima najveću ulogu u povećanju članstva. Osim usmene predaje, kao sredstvo promocije često se koristi mrežna stranica knjižnice i čitateljskog kluba (7 ispitanika) te Facebook stranica (4 ispitanika). Informacije na knjižničnom pultu kao metodu oglašavanja navelo je četvero ispitanika.

Koliko otprilike traje jedan sastanak? Kao što vidimo u tablici 3, uobičajeno je vrijeme trajanja sastanka između jednog i dva sata. Većina je ispitanika naglasila da sastanci znaju potrajati i dulje ako je rasprava zanimljiva.

Tablica 3. Trajanje sastanka čitateljskih klubova

\begin{tabular}{|c|c|}
\hline Trajanje sastanka & Broj klubova \\
\hline 1 sat & 3 \\
\hline 90 min & 2 \\
\hline $90-120$ min & 3 \\
\hline 2 sata & 3 \\
\hline
\end{tabular}

Koliko se mjesečno održi sastanaka čitateljskog kluba? Na ovo su pitanje gotovo svi voditelji odgovorili jednako - jedan sastanak mjesečno. Samo ispitanici iz klubova ČKSS2 i ČKR1 naveli su da se povremeno znaju sastajati i češće, povodom rođendana kluba ili rođendana nekoga od članova.

Gdje se odvijaju sastanci? Svi su ispitanici odgovorili da se njihovi sastanci odvijaju u knjižnici, a gotovo polovina ispitanika odgovorila je da nekada znaju održati sastanak i izvan knjižnice, na otvorenom. Mjesta koja navode su kafić, restoran, plaža, muzej, autobus.

Koji su ciljevi čitateljskog kluba koji vodite? Svaki je ispitanik naveo nekoliko ciljeva kluba, a ciljevi koji se najčešće spominju jesu: razgovor o knjizi na neobavezan način, razmjena mišljenja i dijeljenje iskustava, uvažavanje tuđeg mišljenja, širenje ljubavi prema knjizi, druženje, promocija i poticanje čitanja, širenje znanja, zabava. Budući da su se ispitanici trudili što detaljnije opisati ciljeve, navesti ćemo nekoliko cjelovitih odgovora:

Promicanje i poticanje čitanja kod djece, razvijanje komunikacijskih i socijalnih vještina, sposobnosti izražavanja, interpretacije teksta, bogaćenje rječnika, razvijanje koncentracije, mašte. Učenje argu- 
mentirano razgovarati, uvažavati tuđa mišljenja. Razvijanje tolerancije, empatije, samopouzdanja. Stjecanje novih znanja, informacija, prijateljstava. (ČKS1)

Okupiti djecu i mlade - ljubitelje knjiga i čitanja - u knjižnici i ponuditi im jedan vid kvalitetno provedenog slobodnog vremena, omogućiti im da upoznaju svoje vršnjake sličnih interesa, druže se u knjiškom okruženju, u lijepoj i toploj atmosferi dječjeg odjela, razmjenjuju iskustva i doživljaje, slobodno izražavaju svoje mišljenje, poslušaju drugačija mišljenja, pokušaju sagledati stvari iz drugačijih perspektiva i da se pritom dobro zabave. (ČKR1)

Knjižnica kao mjesto okupljanja i socijalizacije, razvijanje grupe koja će pratiti i ostala događanja u knjižnici. Razvijanje empatije i asertivnosti među generacijama. Razvijanje kazivanja i pripovijedanja. Razvijanje ljubavi i prema starijim knjigama koje su se nekad čitale. (ČKO1)

\section{Koje se sve aktivnosti odvijaju na sastancima u sklopu čitateljskog kluba?}

Čitateljski klubovi održavaju razne aktivnosti na svojim sastancima, ali jedina aktivnost koju su naveli gotovo svi ispitanici jest rasprava i razgovor o knjizi. U sklopu te aktivnosti ispitanici su još navodili razmjenu mišljenja, iznošenje kritičkog mišljenja, uvažavanje tuđeg mišljenja. Ostale aktivnosti koje je spomenulo više ispitanika jesu igre i preporuke knjiga te biranje sljedeće knjige za čitanje. Pod igrama su navodili pitalice, kvizove, igre asocijacija, potragu među knjižnim policama, razne društvene igre (Dixit, Pričosvijet). Neki od ispitanika naveli su i sljedeće aktivnosti za sastanke kluba: vođenje dnevnika kluba, ocjenjivanje knjige, pisanje osvrta na knjigu, susreti s autorima, razgovor o nadolazećim aktivnostima u knjižnici, gledanje filma, hrana i piće, obilježavanje značajnih datuma iz književnosti, promoviranje poezije, likovno izražavanje, igra sa psima. Samo ispitanik u ČKS2 nije naveo nijednu aktivnost posebno, nego je odgovorio da ništa nije zadano i unaprijed pripremljeno te da je sve dozvoljeno osim prevrtanja stola.

Tko bira knjige za čitanje i raspravu? Gotovo u svim čitateljskim klubovima knjige za raspravu biraju zajednički voditelj (najčešće knjižničar) i članovi. Praksa je uglavnom takva da voditelj predloži nekoliko naslova, a zatim članovi glasaju te se za sljedeći susret čita naslov koji dobije najviše glasova. Jedino u čitateljskom klubu ČKR2 naslove bira isključivo voditelj, a u klubu ČKR1 članovi sami biraju naslove.

Koji su kriteriji kod odabira knjiga za čitanje? Na ovo pitanje najviše je ispitanika odgovorilo da je želja članova jedan od najbitnijih kriterija pri odabiru knjiga za čitanje. Sljedeći je najčešće navođen kriterij dostupnost knjiga - klubovi biraju knjige koje se u knjižnici mogu naći u većem broju primjeraka. Naprimjer voditeljica iz ČKR4 navodi kako biraju knjige starije od dvije godine jer se pretpostavlja da je za novije knjige veća potražnja ostalih korisnika. Kriterij koji je 
navelo više ispitanika jest da se biraju knjige koje imaju elemente dobre za raspravu. Tri ispitanika navela su kriterij kvalitete i autentičnosti knjiga. Po jedan ili dva ispitanika naveli su i sljedeće kriterije: zanimljivost radnje, primjerenost uzrastu, žanr, kultni status knjige, dobre kritike, manji broj stranica.

Koji se tipovi knjiga odabiru za čitanje i raspravu? Odabir knjiga za čitanje i raspravu uglavnom ovisi o tome komu je klub namijenjen. Iz odgovora ispitanika možemo vidjeti da se u klubovima za mlade većinom biraju romani za mlade. Tako ispitanik iz ČKP1 navodi da se u njihovu klubu biraju knjige u kojima mladi imaju glavne uloge, a ispitanik iz ČKZ1 navodi da se u njihovu klubu biraju knjige o tinejdžerskim temama. Voditelji klubova za djecu odgovorili su da biraju dječje romane, a ostali su najčešće navodili romane, beletristiku i različite žanrove.

Čitaju li svi članovi kluba istu knjigu za pojedini sastanak ili se čitaju različite knjige pa svatko predstavlja svoju? Na ovo pitanje deset ispitanika odgovorilo je da svi članovi čitaju istu knjigu. Od toga dva ispitanika navode da jedino nakon ljetne stanke svi članovi predstavljaju sve knjige koje su u međuvremenu pročitali. Ispitanik iz ČKS2 navodi kako je uglavnom zadana jedna knjiga, ali ona služi samo kao polazište i nije poželjno da sve ostane na njoj, nego da se povezuje s drugim knjigama, filmovima, filozofijom. Jedino ispitanica iz ČKO1 navodi da na zadanu temu odaberu tridesetak različitih knjiga, a članovi onda među njima biraju određene knjige prema interesima i željama.

Koliki je otprilike omjer knjiga domaćih autora u odnosu na knjige stranih autora o kojima se raspravlja i čita na sastancima? Kao što možemo vidjeti iz tablice 4, u čitateljskim klubovima češće se za čitanje biraju knjige stranih autora. Ispitanici koji navode veću zastupljenost stranih autora uglavnom navode da se u njihovim klubovima domaći autori čitaju vrlo rijetko. Ispitanica iz ČKR4 navodi da su zastupljeniji strani autori, ali se trude ubaciti nekog domaćeg autora barem dvaput godišnje, za "mjesec hrvatske knjige”. Ispitanica iz ČKZ2 čak navodi da njezini članovi ne žele čitati domaće autore. Ispitanici koji navode da se u njihovim klubovima domaći i strani autori čitaju podjednako zapravo navode da su to većinom njihova nastojanja i trud da se održi takav omjer. Od tri čitateljska kluba čiji voditelji navode prednost domaćih autora, u jednom se klubu čitaju samo domaći autori (ČKZ1).

Tablica 4. Što se čita više u čitateljskim klubovima - strani ili domaći autori?

\begin{tabular}{|l|c|}
\hline \multicolumn{1}{|c|}{ Autori } & Broj klubova \\
\hline više se čitaju strani autori & 7 \\
\hline više se čitaju domaći autori & 3 \\
\hline podjednako se čitaju strani i domaći autori & 3 \\
\hline
\end{tabular}


Koliko se često članovi uključuju u rasprave o knjigama? Za koje se tipove knjiga češće uključuju u rasprave (možete navesti primjer knjige i pojasniti zašto je rasprava bila intenzivna)?

Svi su ispitanici uglavnom odgovorili da se članovi uključuju u raspravu na svakom susretu. Neki ispitanici nisu odgovarali na drugi dio pitanja. Navodimo pojedine odgovore:

Članovi se uključuju u raspravu ovisno o njihovom samopouzdanju i sposobnosti izražavanja. Voditelj oprezno potiče na raspravu i one koji su povučeniji kada osjeti da je dobar trenutak. (ČKS1)

Ponekad bi ljudi znali doći na sastanak samo da bi uživali u vatrometu ideja i kreativnosti rasprave, bez da i sami sudjeluju u istoj; ipak, bit kluba je u raspravi i uglavnom budu svi uključeni. Intenzivna rasprava je standard 'Knjigofila', a kad su u pitanju knjige kao npr. 'Rakova obratnica', onda debata bude beskompromisna poput

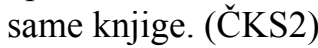

Na koje načine potičete rasprave o knjigama? Većinom su svi ispitanici odgovorili da rasprave potiču postavljanjem različitih pitanja o temi, likovima, stilu. Ispitanik iz ČKS2 navodi da je problem zaustaviti raspravu kad krene, odnosno da ju nema potrebe dodatno poticati. Ispitanik iz ČKR1 navodi da, osim postavljanjem pitanja, raspravu potiče na način da članove potiče da se pokušaju staviti na mjesto likova te upućivanjem na kritike o djelu i traženjem citata. Ispitanica iz ČKP2 navela je da se kod njih rasprava odvija spontano.

Možete li opisati u kratkim crtama raspravu o nekoj knjizi koja vam je zbog nečega ostala u sjećanju? Odgovori na ovo pitanje bili su dosta individualni, dok neki voditelji nisu dali odgovor. Navest ćemo pojedine odgovore:

Rasprava o ‘Ženi kojoj sam čitao' bila je vrlo živa zbog toga što su članovi bili podijeljeni između toga podržavaju li protagonisticu ili ju samo osuđuju zbog njezinih postupaka. (ČKR2)

'Pokoravanje' M. Houellebecqa koja je zbog same teme izazvala živu raspravu i podijelila članstvo, ocjene su bile od 2 do 5. Ili 'Mramorna koža' naše S. Drakulić zbog same tematike, odnosa majke i kćeri. (ČKR3)

Vukelić, Vilma: Tragovi prošlosti. Naslov i nije bio novost jer je velika većina članstva knjigu već pročitala, ali je izazvala lijepa sjećanja na neko prošlo vrijeme, čak i djetinjstvo, te pomalo i ponos što smo

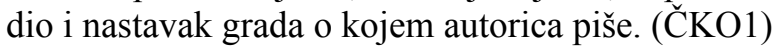


Imate li na sastancima uvijek ista pitanja o knjigama? Ako da, možete li navesti primjere tih pitanja? Četvero ispitanika navodi da se pitanja mijenjaju ovisno o knjizi koja je na repertoaru, odnosno rasprava se odvija spontano. Ispitanici iz ČKS2 i ČKO1 navode kako su na njihovim sastancima samo početna pitanja uvijek ista: ‘Tko će prvi reći svoje mišljenje?' ili ‘Što vam se svidjelo, a što ne u knjizi?'. Ostatak rasprave odvija se spontano. Ovo su pitanja koja pojedini voditelji postavljaju na sastancima:

Je li vam se svidjela knjiga? Kojom biste ju ocjenom ocijenili od 1 do 5? Koji vam je dio knjige najzanimljiviji? Zašto? Sviđaju li vam se glavni lik i njegovi postupci? Što biste promijenili u knjizi? Sviđa li vam se kraj? (ČKS1)

Sviđa li ti se knjiga i zašto? Koju bi joj ocjenu dao/dala? Zašto, što joj nedostaje do desetke? Što bi ti promijenio/promijenila? Koji te se lik najviše dojmio? Jesi li se uspjela/uspio vezati uz neki lik? Koji ti je lik najsličniji i po čemu? Koji ti je najzanimljiviji dio knjige? Najljepše misli, najbolji ulomci i sl. (ČKR1)

U većini klubova postavljaju se dosta slična pitanja. Pitanje koje se najčešće postavlja bilo bi 'Je li vam se svidjela knjiga?'. Ostala pitanja koja se ponavljaju jesu pitanja o likovima, o završetku knjige te kako bi članovi ocijenili knjigu i što bi promijenili u njoj.

Koje su po vašem mišljenju glavne prednosti i pozitivne strane čitateljskog kluba koji vodite? Koje su glavne poteškoće u vođenju i radu čitateljskog kluba? Možete li ukratko opisati ili dati primjer jedne ili dviju glavnih poteškoća? Čime ste zadovoljni u radu kluba, a čime niste? Prednosti čitateljskog kluba koje se najčešće spominju jesu druženje i upoznavanje novih ljudi, kvalitetno provođenje slobodnog vremena te entuzijazam članova. Većina ispitanika navodi da članovi vole dolaziti na susrete, razgovarati o knjizi, razmjenjivati mišljenja s drugima. Većina članova svoj klub doživljava kao ugodno i opušteno mjesto druženja u kojem su slobodni iznositi svoja mišljenja i razmjenjivati iskustva s ostalima. Nedostatak koji se najčešce spominje jest nedovoljan broj primjeraka knjiga u knjižnici. Većina ispitanika navodi da izbjegavaju birati nove i popularne naslove jer se oni najčešće posuđuju u knjižnici pa svi članovi ne bi mogli doći do svog primjerka. Ispitanici koji svoje sastanke održavaju u manjim ograncima navode da je problem to što članovi često moraju knjige posuđivati u drugim ograncima jer u njihovu ogranku nema dovoljno primjeraka. Ispitanica iz ČKR4 navodi da je mnogo veći interes za sudjelovanje u klubu nego što zapravo ima članova, ali budući da im ne može osigurati primjerke, ne može ih primiti u klub. Još jedan nedostatak koji navodi nekoliko ispitanika jest odabir termina sastanaka 
i nedostatak vremena kod članova. Članovi imaju razne druge obveze koje je teško uskladiti sa slobodnim terminima u knjižnici.

\section{Koja biste tri glavna savjeta dali osobama koje žele osnovati čitateljski klub?}

Navodimo nekoliko informativnih i zanimljivih odgovora ispitanika:

Ako se radi o dječjem čitateljskom klubu, treba voditi računa da su djeca približne dobi kako bi im interesi za čitanje bili što sličniji i kako bi mogli ravnopravno sudjelovati u raspravi s obzirom na njihovu intelektualnu i emocionalnu zrelost. Dopustiti djeci da odlučuju što žele čitati, jer svaka je knjiga dobra za raspravu, pa i onda kada zaključimo da nam se knjiga ne sviđa. Štoviše, tako mogu uočiti razlike u kvaliteti. Raspravu treba voditi ležerno, paziti da svako dijete ima priliku nešto reći, brinuti o dobrom raspoloženju i ugodnoj atmosferi. (ČKS1)

Voditelj kluba mora biti jako zainteresiran za svaku knjigu koju obrađuje. Ako on nije pun pozitivne knjigofilske energije, neće biti ni ostali. Članove nije potrebno dovlačiti u klub po svaku cijenu, nego oni sami moraju poželjeti biti dijelom jednog tako posebnog iskustva. Ako su gornja dva savjeta urodila plodom, treći nije potreban. (ČKS 2$)$

Dobro promisliti za koje skupine osnovati klub - po dobi ili npr. samo za čitateljice. Za klub je potrebno osigurati i prostor i vrijeme, a i građu za čitanje (jako je teško osigurati dovoljan broj knjiga ako npr. svi čitaju isti naslov). Možda osigurati i neke dodatne sadržaje, npr. osvježenje ili uz neki predloženi naslov pustiti film, ukoliko je ekraniziran. (С̆KO1)

Prijateljska opuštajuća atmosfera, ravnopravno sudjelovanje u raspravama s maksimalnom tolerancijom za različita razmišljanja. (ČKZ1)

Prilagoditi se grupi - njihovim željama i interesima. Omogućiti da i oni koji nisu pročitali knjigu mogu doći na sastanak i pripremiti aktivnosti u koje će se nakon razgovora o knjizi i oni moći uključiti. (ČKZ2)

\section{Za kraj, molimo vas da navedete na kojem knjižničnom odjelu radite i} koja su vam glavna radna zaduženja u knjižnici. Osim tri voditeljice iz riječkih čitateljskih klubova, svi ispitani voditelji klubova zaposleni su kao knjižničari u svojim knjižnicama. Voditelji klubova rade na raznim pozicijama u knjižnici: kao informatori, dječji knjižničari, pomoćni knjižničari, a jedan je voditelj ravnatelj 
knjižnice. Dvije voditeljice koje ne rade kao knjižničarke, već obavljaju posao voditeljice kao volonterke, nisu navele koje je njihovo zanimanje. Jedna voditeljica volonterka je studentica.

\subsection{Rasprava}

Iako je anketa bila dosta dugačka i sva su pitanja bila otvorenog tipa te je zahtijevala znatno vrijeme za ispunjavanje, svi ispitanici odgovorili su na gotovo sva pitanja i potpitanja. Već to može biti pokazatelj entuzijazma i angažiranosti voditelja, pokazatelj toga da drže do svojih klubova i nije im teško uložiti vrijeme i trud kako bi opisali na koji način vode klub i kako on djeluje.

Istraživanje je pokazalo da u ispitanim čitateljskim klubovima među članovima nisu podjednako zastupljene sve dobne skupine. Primjerice u Gradskoj $i$ sveučilišnoj knjižnici Osijek djeluje samo jedan klub i on je namijenjen korisnicima treće životne dobi, a u Gradskoj knjižnici i čitaonici Pula djeluju dva kluba namijenjena samo djeci i mladima. Budući da su to prilično veliki gradovi i interesa za sudjelovanje vjerojatno ne bi nedostajalo, bilo bi poželjno da njihove gradske knjižnice imaju čitateljske klubove za ostale dobne skupine. U tom su smislu dobar primjer gradske knjižnice u Splitu, Rijeci i Zadru, koje imaju čitateljske klubove za osobe različitih dobi.

Istraživanjem je utvrđeno da čitateljski klubovi broje od 7 do 20 članova, a većina članova su žene. Razlozi za to nisu poznati, moglo bi se napraviti istraživanje kojim bi se nastojalo utvrditi zašto čitateljski klubovi više privlače žene nego muškarce.

Na pitanje na koji način obavještavaju nove članove o postojanju i radu čitateljskog kluba, voditelji su najčešće odgovarali da se to čini usmenom predajom i da je tako najučinkovitije jer postojeći članovi iz prve ruke prenose dobre vijesti o klubovima čiji su članovi, savjetuju svoje prijatelje, pozivaju ih na sastanke. Na taj način potencijalni članovi izravno saznaju sve o klubu, a jedna od prednosti može biti i to da već imaju nekog poznanika u klubu te ih to može dodatno privući. Sredstva koja klubovi još najčešće koriste za oglašavanje jesu mrežna i Facebook-stranica te obavijesti u samoj knjižnici. Preko navedenih sredstava oglašavanja za klub mogu doznati samo posjetitelji mrežne i Facebook-stranice knjižnice pa bi bilo dobro da se klubovi oglašavaju češće i drugim metodama, naprimjer postavljanjem plakata na frekventnim mjestima u gradu, dijeljenjem letaka. Tako bi se možda privukli i oni koji inače ne pristupaju knjižnici fizički ni preko interneta.

Sastanci u čitateljskim klubovima uglavnom se održavaju jednom mjesečno, traju od jednog do dva sata, a mjesto sastanka najčešće je knjižnica. Gotovo svi voditelji naveli su kako bi voljeli da se sastanci održavaju češće, ali to zbog obveza 
članova nije izvedivo. Mjesečni ritam sastanaka na neki je način i logičan jer članovima uz druge obveze treba neko vrijeme da pročitaju knjigu. Održavanje sastanaka izvan knjižnice, na otvorenom, zasigurno unosi dinamiku i neformalnost.

Ciljevi čitateljskih klubova ponešto se razlikuju ovisno o tome okupljaju li djecu, mlade ili odrasle, ali zajednički im je cilj razgovor i druženje te razmjena mišljenja. Klubovi za djecu, osim toga, za cilj imaju i promicanje čitanja, što je razumljivo jer je važno djecu poticati da zavole čitanje od malih nogu. Sudjelovanjem u čitateljskim klubovima članovi svih dobi uče se komunikacijskim vještinama, izražavanju i uvažavanju tuđeg mišljenja. Putem rasprava o knjigama članovi usvajaju mnogo novih informacija i znanja, a budući da rasprava često skrene na razgovore o povezanim temama i društvenim pitanjima, budući da se iznose vlastita iskustva, članovi uče i jedni od drugih. Kao najčešća aktivnost koja se odvija na sastancima navodi se rasprava o knjigama, što je logično jer je to zapravo srž samog čitateljskog kluba i aktivnost oko koje se sve okuplja. Navode se i dodatne aktivnosti na sastancima, kao što su igre, ocjenjivanje knjige i biranje sljedeće knjige, crtanje. One se najčešće održavaju kao uvod u raspravu ili na kraju sastanka, za opuštanje. Aktivnosti ovise i o dobi, tako da se djecu češće treba motivirati dodatnim aktivnostima, igranjem igara, vođenjem dnevnika, hranom i pićem. Nekoliko voditelja navodi kako znaju upriličiti susrete s autorima, što je poseban doživljaj za članove jer imaju priliku čuti kako je nastala priča te postaviti pitanja vezana uz djelo i autora.

Knjige se za sljedeći susret uglavnom biraju zajedničkim dogovorom voditelja i članova. Budući da su gotovo svi voditelji knjižničari po zanimanju, njihovi stručni savjeti u kombinaciji sa željama korisnika optimalno su rješenje za dobar odabir knjiga. Što se tiče kriterija, upravo su želje korisnika na prvom mjestu. Čitateljski klubovi i nastaju zbog ljudi koji se okupljaju u njima, tako da se njihove želje nedvojbeno moraju uzimati u obzir, a i rasprava će biti življa ako je knjiga pročitana s uživanjem. Na drugom se mjestu kao kriterij za odabir knjiga navodi dostupnost knjiga. Knjižničari to također navode i kao jednu od poteškoća u radu kluba jer često moraju odustajati od nekih naslova, a posebno od novijih knjiga, zbog velike potražnje ostalih korisnika i nedovoljno primjeraka u knjižnici.

Kada govorimo o tome koje se knjige biraju za rasprave, većinom to ovisi o dobi članova - djeca čitaju dječje romane, mladi tinejdžerske romane, a ostale dobi čitaju raznoliku literaturu, ali najviše beletristiku. U nekoliko čitateljskih klubova čitaju se pretežno ili čak isključivo hrvatski autori. Ta je praksa pohvalna jer se tako njeguje domaće stvaralaštvo. Ipak, puno se češće za čitanje biraju strani autori.

Na pitanje o tome čitaju li svi članovi kluba istu knjigu za pojedini sastanak ili se čitaju različite knjige pa svatko predstavlja svoju, velika većina ispitanika odgovorila je da svi članovi čitaju istu knjigu. Može se pretpostaviti da je razlog da članovi u klubovima uglavnom istodobno čitaju istu knjigu u tome što su onda 
svi sudionici upoznati s istim sadržajem o kojemu će se govoriti na sastanku. Rasprave se mogu zasnivati na različitim doživljajima, interpretacijama i naglascima vezanim uz istu knjigu. Mogući problem kod te prakse jest da knjižnica možda neće imati dovoljno primjeraka knjige koja je određena za čitanje ili da će izbor knjiga za sastanke kluba biti previše određen prema tome koje knjižnica knjige ima u više primjeraka. Mogući je nedostatak i to da će se članovi kluba upoznati na sastancima s manje knjiga nego kada bi svi ili barem neki od članova za pojedini sastanak trebali pročitati različite knjige.

Članovi ispitanih čitateljskih klubova uglavnom su aktivni i svi sudjeluju u raspravama, tako da često nema potrebe da voditelji potiču raspravu, a nekada njihovim voditeljima bude čak problem zaustaviti raspravu. To je znak da oni vole čitati i da se osjećaju opušteno u svome klubu. Ipak, u nekim klubovima imaju neka univerzalna pitanja na koja se uvijek odgovara, većinom o tome je li im se knjiga svidjela, kako bi ju ocijenili, što bi u njoj promijenili.

Voditelji čitateljskih klubova u anketi su opisali čime su zadovoljni, odnosno koje su prednosti, a koji nedostaci i poteškoće u radu i vođenju kluba. Možemo vidjeti da su prednosti čitateljskih klubova mnogostruke. Ljudi u njima na kvalitetan način mogu provesti slobodno vrijeme, zadovoljiti svoje društvene potrebe upoznajući se i družeći s ljudima, steći nove informacije, znanja i iskustva, zabaviti se te još mnogo toga što voditelji nisu ni naveli. Odgovori su pokazali da su voditelji u velikoj mjeri zadovoljni radom svojih klubova, a posebno članovima koji ih čine, jer svi ističu da članovi rado dolaze na sastanke, sudjeluju u raspravama, a njihov je entuzijazam ono što održava klub. Osim nedovoljnog broja primjeraka, koji gotovo svi voditelji navode kao nedostatak, nedostatak koji se također češće

spominje jest dogovor oko termina sastanka. Članovi imaju i druge obveze pa je nekada teško uskladiti termine, ali većina klubova ima ustaljen termin susreta, npr. prve subote u mjesecu ili posljednjeg utorka u mjesecu.

Voditelji čitateljskih klubova dali su i savjete za njihovo vođenje. Neke od preporuka i preduvjeta za uspješan rad čitateljskog kluba jesu da voditelj kluba voli knjige i čitanje, da ima potrebne organizacijske vještine te da na sastancima kluba nastoji poticati ravnopravnu raspravu u opuštenoj i ugodnoj atmosferi.

\section{Zaključak}

Narodne knjižnice otvorene su za sve članove zajednice. One su mjesta okupljanja i mjesta na kojima ljudi vole provoditi slobodno vrijeme. Glavne su djelatnosti narodne knjižnice osiguravanje građe i pružanje usluga korisnicima. Jedna od bitnih zadaća narodne knjižnice jest promicanje čitanja. Upravo su čitanje i rasprava o pročitanome u fokusu djelovanja knjižničnih čitateljskih klubova. Čitateljski klubovi idealni su za promicanje čitanja jer okupljaju čitatelje koji uživaju u druženju i razgovorima o pročitanome s drugim čitateljima. U ovom 
radu istražili smo koliko su prisutni čitateljski klubovi u narodnim knjižnicama šest velikih gradova u Hrvatskoj, koja su im obilježja i prakse te koja su iskustva i preporuke njihovih voditelja. S obzirom na dobivene rezultate, možemo zaključiti kako su čitateljski klubovi u istraženim narodnim knjižnicama vrlo aktivni, a njihovi voditelji posvećeni radu klubova. Tema knjižničnih čitateljskih klubova može se dodatno istražiti u različitim smjerovima. Naprimjer može se provesti istraživanje među članovima čitateljskih klubova kako bi se pružila njihova perspektiva; u istraživanje se može uključiti dodatne čitateljske klubove kako bi se istražilo aspekte njihova djelovanja; može se usporediti rad domaćih i stranih čitateljskih klubova. Nadamo se da će ovaj rad biti koristan i poticajan za daljnja istraživanja ove tematike te da može doprinijeti unapređenju rada postojećih čitateljskih klubova, kao i osnivanju novih klubova.

\section{LITERATURA}

Aleksić, Lj.; S. Zec. Knjižnične usluge i službe s gledišta korisnika-prilozi za bibliografiju. // Vjesnik bibliotekara Hrvatske 60, 2-3(2017), 317-339.

Alvarez-Alvarez, C. Book clubs: an etnographic study of an innovative reading practice in Spain. // Studies in Continuing Education 38, 2(2016), 228-242.

Bašić, I. O čitateljskim grupama: metodički priručnik s primjerima dobre prakse. Zagreb: Balans centar za logopedagogiju i biblioterapiju, 2014.

Bokan, A.; D. Cupar. Promocija i promicanje čitanja u narodnim knjižnicama Republike Hrvatske. // Libellarium 10, 1(2017), 51-76. [citirano: 2019-10-14]. Dostupno na: http://www.libellarium.org/index.php/libellarium/article/view/290.

Bokan, A.; Lj. Poljak. Provođenje slobodnog vremena čitajući u knjižnici. // Vjesnik bibliotekara Hrvatske 61, 1(2018), 173-199.

Gradska knjižnica Marka Marulića u Splitu. [2019-08-24]. Dostupno na: https://www. gkmm.hr.

Gradska knjižnica Rijeka. [2019-08-24]. Dostupno na: https://gkr.hr.

Gradska i sveučilišna knjižnica Osijek. [2019-08-24]. Dostupno na: https://www.gskos. unios.hr.

Gradska knjižnica Zadar. [2019-08-24]. Dostupno na: www.gkzd.hr.

Gradska knjižnica Slavonski Brod. [2019-08-24]. Dostupno na: https://www.gksb.hr.

Gradska knjižnica i čitaonica Pula. [2019-08-24]. Dostupno na: www.gkc-pula.hr.

Habermas, J. The structural transformation of the public sphere: an inquiry into a category of bourgeois society. MIT Press, 1991. 
Healy, A. Giving readers a voice: book discussion groups. [citirano: 2019-08-24]. Dostupno na: http://www.ala.org/aboutala/offices/publishing/booklist/booklinks/resources/bookdiscussion.

IFLA-ine smjernice za narodne knjižnice / uredile Christie Koontz i Barbara Gubbin. 2. hrvatsko izd. Zagreb: Hrvatsko knjižničarsko društvo, 2011.

Ivanković, B.; N. Mlinko. Knjižnica kao prostor flanerije. // Vjesnik bibliotekara Hrvatske 60, 1(2017), 183-191.

Kolarić, A.; S. Šimić; V. Štivić; Ž. Žentil Barić. Čitateljski blogovi Tragači i Knjiški frikovi: usluge za djecu i mlade na Web-u 2.0. // Vjesnik bibliotekara Hrvatske 56, 3(2013), 91-100.

Kosmicki, E. A. A book club for children with autism spectrum disorder: a thesis submitted in partial fulfillment of the requirements for the designation University Honors with Distinction. University of Northern Iowa, 2016. [citirano: 2019-10-14]. Dostupno na: https://scholarworks.uni.edu/cgi/viewcontent.cgi?article=1228\&context $=$ hpt.

Krpan, K.; I. Klak Mršić; V. Cej. Primjena razvojne biblioterapije u radu s djecom i mladima u narodnoj knjižnici. // Vjesnik bibliotekara Hrvatske 61, 1(2018), 345361.

Pejić, I. Narodne knjižnice: potpora formalnom i neformalnom obrazovanju - visoko obrazovanje. // Radovi Zavoda za znanstvenoistraživački i umjetnički rad u Bjelovaru, 3(2009), 97-112.

Plevnik, D. Tolle lege: za slobodu čitanja. Zagreb: Nacionalna i sveučilišna knjižnica, 2012.

Stepanić, A. Čitateljski klubovi u zagrebačkim narodnim knjižnicama: diplomski rad. Zagreb: Filozofski fakultet Sveučilišta, 2014.

Tyler, J. E. The people who do 'this' in common: book clubs as 'everyday activists': doktorska disertacija. Knoxville: University of Tennessee, 2014. [citirano: 2019-1014]. Dostupno na: https://trace.tennessee.edu/utk_graddiss/2778/.

Vrana, R.; J. Kovačević. Kakvu narodnu knjižnicu želimo? Istraživanje korisnika Knjižnice i čitaonice Bogdana Ogrizovića. // Vjesnik bibliotekara Hrvatske 61, 2(2018), str. 47-71. 
Prilog 1

Pitanja u anketi:

1. Koliko članova ima čitateljski klub u vašoj knjižnici?

2. Imate li članove svih uzrasta? U kojoj je otprilike dobi najviše članova kluba?

3. Koliko je otprilike muških, a koliko ženskih članova?

4. Kako sve potencijalni članovi kluba mogu saznati da klub postoji i koje su mu aktivnosti? Kako pridobivate nove članove?

5. Koliko se mjesečno održi sastanaka čitateljskog kluba?

6. Gdje se odvijaju sastanci?

7. Koliko otprilike traje jedan sastanak?

8. Koji su ciljevi čitateljskog kluba koji vodite?

9. Koje se sve aktivnosti odvijaju na sastancima u sklopu čitateljskog kluba?

10. Tko bira knjige za čitanje i raspravu?

11. Koji su kriteriji kod odabira knjiga za čitanje?

12. Koji se tipovi knjiga odabiru za čitanje i raspravu?

13. Koliki je otprilike omjer knjiga domaćih autora u odnosu na knjige stranih autora koje se čita i o kojima se raspravlja na sastancima?

14. Čitaju li svi istu knjigu za pojedini sastanak ili se čitaju različite knjige pa svatko predstavlja svoju?

15. Koliko se često članovi uključuju u rasprave o knjigama? Za koje se tipove knjiga češće uključuju u rasprave (možete navesti primjer knjige i objasniti zašto je rasprava bila intenzivna)?

16. Na koje načine potičete rasprave o knjigama?

17. Možete li opisati u kratkim crtama raspravu o nekoj knjizi koja vam je zbog nečega ostala u sjećanju? 
18. Imate li na sastancima uvijek neka ista pitanja o knjigama? Ako da, možete navesti primjere tih pitanja.

19. Koje su po vašem mišljenju glavne prednosti i pozitivne strane čitateljskog kluba koji vodite, a koji su nedostaci i zapreke u radu.

20. Koje su glavne poteškoće u vođenju i radu čitateljskog kluba? Možete li ukratko opisati ili dati primjer jedne ili dviju glavnih poteškoća?

21. Čime ste zadovoljni u radu kluba, a čime niste?

22. Koja biste tri glavna savjeta dali osobama koje žele osnovati čitateljski klub?

23. Ako postoje neki tekstovi u tiskanim dokumentima ili na mreži o čitateljskom klubu koji vodite, navedite imena tih tekstova tj. mrežne adrese gdje se mogu pronaći.

24. Ako imate bilo koju dodatnu temu koju želite istaknuti u vezi s vašim čitateljskim klubom ili općenito o čitateljskim klubovima, molimo da to ovdje napišete.

25. Za kraj, molimo vas da navedete na kojem knjižničnom odjelu radite i koja su vam glavna radna zaduženja u knjižnici. 